\section{Yeast calcineurin regulates nuclear localization of the Crz1p transcription factor through dephosphorylation}

\author{
Angelike Stathopoulos-Gerontides, ${ }^{1}$ Jim Jun Guo, \\ and Martha S. Cyert ${ }^{2}$ \\ Deptartment of Biological Sciences, Stanford University, \\ Stanford, California 94305-5020 USA
}

Calcineurin, $\mathrm{a} \mathrm{Ca}^{2+} /$ calmodulin dependent protein phosphatase, regulates $\mathrm{Ca}^{2+}$-dependent processes in a wide variety of cells. In the yeast, Saccharomyces cerevisiae, calcineurin effects $\mathrm{Ca}^{2+}$-dependent changes in gene expression through regulation of the Crz1p transcription factor. We show here that calcineurin dephosphorylates Crz1p and that this results in translocation of Crz1p to the nucleus. We identify a region of Crz1p that is required for calcineurin-dependent regulation of its phosphorylation, localization, and activity, and show that this region has significant sequence simlarity to a portion of NF-AT, a family of mammalian transcription factors whose localization is also regulated by calcineurin. Thus, the mechanism of $\mathrm{Ca}^{2+} /$ calcineurin-dependent signaling shows remarkable conservation between yeast and mammalian cells.

Received January 25, 1999; accepted February 5, 1999.

Calcineurin is a conserved $\mathrm{Ca}^{2+} /$ calmodulin-dependent protein phosphatase that plays a critical role in $\mathrm{Ca}^{2+}$ signaling. The activation of $\mathrm{T}$ lymphocytes by antigen requires calcineurin, and the immunosuppressive drugs, FK506 and cyclosporin A, act by inhibiting this phosphatase (Friedman and Weissman 1991; Liu et al. 1991a; Clipstone and Crabtree 1992; O'Keefe et al. 1992). NF$\mathrm{AT}$, a family of mammalian transcription factors, is the critical target of calcineurin-dependent regulation for $\mathrm{T}$ cell activation as well as for other other processes such as cardiac development and hypertrophy (Clipstone and Crabtree 1992; O'Keefe et al. 1992; Rao et al. 1997; de la Pompa et al. 1998; Molkentin et al. 1998; Ranger et al. 1998). Dephosphorylation of NF-AT by calcineurin results in its translocation to the nucleus, where it activates transcription (Flanagan et al. 1991; Jain et al. 1993; Shaw et al. 1995; Beals et al. 1997).

In the yeast Saccharomyces cerevisiae, calcineurin is required for cell viability under specific environmental conditions. Calcineurin is a heterodimer of a catalytic subunit (encoded by the CNA1 and CNA2 genes) and a regulatory subunit (encoded by CNB1) (Cyert et al. 1991;

${ }^{1}$ Present address: Department of Molecular and Cell Biology, University of California, Berkeley, California 94720 USA.

${ }^{2}$ Corresponding author.

E-MAIL mcyert@leland.stanford.edu; FAX (650) 725-8309.
Liu et al. 1991b; Cyert and Thorner 1992). Calcineurin-

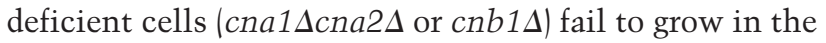
presence of $\mathrm{Na}^{+} / \mathrm{Li}^{+}, \mathrm{Mn}^{2+}$, or alkaline $\mathrm{pH}$, and lose viability during prolonged incubation with mating pheromone (Nakamura et al. 1993; Mendoza et al. 1994; Moser et al. 1996; Pozos et al. 1996; Withee et al. 1997). All of these conditions, as well as addition of $\mathrm{Ca}^{2+}$ to the growth medium, induce $\mathrm{Ca}^{2+} /$ calcineurin-dependent gene expression (Mendoza et al. 1994; Mazur et al. 1995; Cunningham and Fink 1996).

Previously, we elucidated the mechanism by which transcription of one target gene, FKS2, is activated in response to $\mathrm{Ca}^{2+}$. A $24 \mathrm{bp}$ region of the FKS2 promoter, the CDRE, is sufficient to direct $\mathrm{Ca}^{2+}$-induced gene expression, and this transcription requires both calcineurin and the Crzlp transcription factor (Stathopoulos and Cyert 1997). crz1s mutants fail to activate calcineurin-dependent transcription, and display growth and viability defects similar to those of calcineurin mutants (Matheos et al. 1997; Stathopoulos and Cyert 1997). Thus, many of the physiological functions of calcineurin in yeast are mediated by its regulation of Crzlp.

In this report we describe the mechanism by which calcineurin regulates Crzlp activity. We demonstrate that calcineurin dephosphorylates Crzlp in vitro, and that Crzlp localization changes from cytosolic to nuclear subsequent to calcineurin activation in vivo. Furthermore, we identify a domain of Crzlp that is required for calcineurin-dependent regulation of its phosphorylation, localization, and activity. This domain of Crzlp has significant sequence similarity to a portion of NF-ATc [the serine-rich region (SRR)], which is similarly required for its regulation by calcineurin (Beals et al. 1997). Thus, these studies establish that calcineurin regulates the phosphorylation and localization of Crzlp in yeast, and identify Crzlp as a substrate of calcineurin. Furthermore, our observations reveal that the mechanism by which $\mathrm{Ca}^{2+} /$ calcineurin regulates gene expression in yeast and mammalian cells is strikingly similar.

\section{Results and Discussion}

To elucidate the mechanism by which calcineurin controls Crzlp activity, we examined whether Crzlp phosphorylation is modulated by calcineurin. Crzlp isolated from calcineurin-deficient cells migrates on SDS-polyacrylamide gels with a significantly larger apparent molecular mass than Crzlp isolated from wild-type cells (118,000 vs. 97,000; Fig. 1, lane 1 vs. lane 6). Treatment of the larger $(118 \mathrm{kD})$ form of Crzlp with calcineurin, $\mathrm{Ca}^{2+}$ and calmodulin in vitro converted it to the smaller (97 kD) form (Fig. 1, lane 8). This change in apparent molecular mass was due to calcineurin-mediated dephosphorylation, as it was dependent on calcineurin and was blocked either by the addition of the $\mathrm{Ca}^{2+}$ chelator, EGTA, or by the calcineurin inhibitor, cypermethrin (Fig. 1, lanes 7,9,10). Incubation with calcineurin did not alter the apparent molecular mass of Crzlp isolated from 


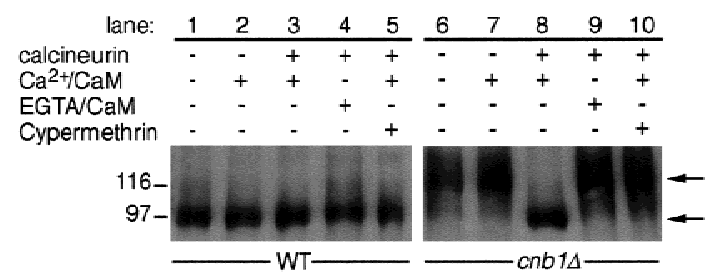

Figure 1. Crzlp is dephosphorylated by calcineurin in vitro. HA-Crzlp was purified by immunoprecipitation from crz1 $1 \Delta$ strains ASY472 (WT) and ASY475 (cnb1 4 ) containing pAMS466 [YEp(HA-CRZ1)], incubated under different conditions as noted, and analyzed by PAGE and Western blotting (see Materials and Methods). (Lanes 1,6) HA-Crzlp incubated with buffer; (lanes 2,7) HA-Crzlp incubated in buffer with $20 \mathrm{~mm}$ $\mathrm{CaCl}_{2}$, and calmodulin; (lanes 3,8) HA-Crzlp incubated in buffer with $20 \mathrm{mM} \mathrm{CaCl}_{2}, 83$ units of calmodulin, and 0.8 unit of calcineurin, as described in Materials and Methods; (lanes 4,9) HA-Crzlp incubated in buffer with calcineurin and calmodulin plus 100 mM EGTA; (lanes 5,10) HA-Crzlp incubated in buffer with $20 \mathrm{mM} \mathrm{CaCl}_{2}$ and calmodulin plus calcineurin that was preincubated for $15 \mathrm{~min}$ at $30^{\circ} \mathrm{C}$ with $100 \mu \mathrm{M}$ cypermethrin.

wild-type cells (Fig. 1, lane 3). These data indicate that Crzlp is hyperphosphorylated in cells lacking calcineurin, and that it serves as a substrate for calcineurin in vitro.

Next, we sought to identify properites of Crzlp that are modulated by phosphorylation. Calcineurin-mediated dephosphorylation was not required for Crzlp to associate with DNA. A CDRE-specific protein-DNA complex containing the Crzlp protein forms in extracts of wild-type cells (Stathopoulos and Cyert 1997), and an identical complex was observed in extracts of calcineurin deficient cells (data not shown).

To examine localization of Crzlp, we constructed a fusion protein containing green fluorescent protein (GFP) and Crzlp. GFP-Crzlp fully complements the growth defects of a $\operatorname{crz} 1 \Delta$ strain and mediates $\mathrm{Ca}^{2+}$-induced calcineurin-dependent transcriptional activation (data not shown and Fig. 5B, below). As was observed for Crzlp, the apparent molecular mass of GFP-Crzlp is also larger in calcineurin-deficient strains than in wildtype strains (see Fig. 5D, below). Thus, the function and regulation of GFP-Crzlp and Crzlp are indistinguishable. In either wild-type or calcineurin mutant cells cultured under standard conditions, GFP-Crzlp localized to the cytosol (Fig. 2A). However, when wild-type cells were incubated with $200 \mathrm{~mm} \mathrm{Ca}^{2+}$, GFP-Crzlp became nuclear within $10 \mathrm{~min}$ (Fig. 2B, top). In contrast, in calcineurin-mutant cells treated with $200 \mathrm{~mm} \mathrm{Ca}{ }^{2+}, \mathrm{GFP}-$ Crzlp remained cytosolic (Fig. 2B, bottom). In wild-type cells, nuclear localization of GFP-Crzlp was also induced by addition of $800 \mathrm{~mm} \mathrm{NaCl}$ or incubation at high temperature $\left(37^{\circ} \mathrm{C}\right)$. However, both of these treatments, as well as addition of lower concentrations of $\mathrm{Ca}^{2+}(150$ $\mathrm{mm}$ or less) resulted in $<50 \%$ cells with complete nuclear localization (data not shown). Thus, several conditions that activate calcineurin/Crz1-dependent transcription (Mendoza et al. 1994; Matheos et al. 1997; Stathopoulos
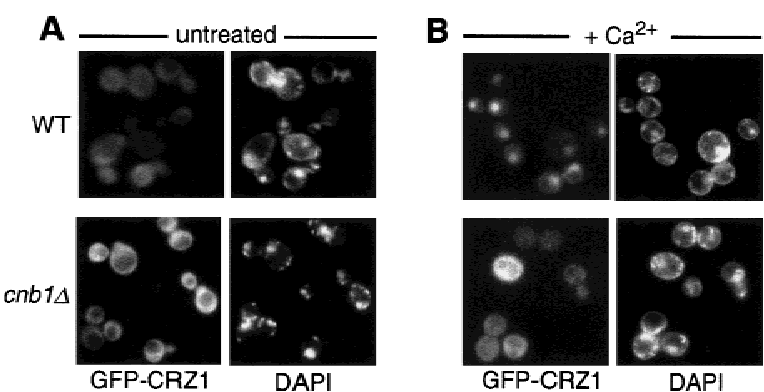

Figure 2. Translocation of GFP-CRZ1 to the nucleus is in duced by $\mathrm{Ca}^{2+}$ addition and requires calcineurin. Living cells of strain ASY472 (WT) or ASY475 (cnb1山) containing pAMS463 (GFP-CRZ1) were grown at $21^{\circ} \mathrm{C}$, incubated briefly with DAPI to stain DNA, and analyzed by fluorescence microscopy to observe GFP-Crzlp localization (GFP-CRZ1) or nuclear staining (DAPI). (A) Untreated cells; (B) cells incubated with $200 \mathrm{~mm}$ $\mathrm{CaCl}_{2}$ for $10 \mathrm{~min}$ at $21^{\circ} \mathrm{C}\left(+\mathrm{Ca}^{2+}\right)$.

and Cyert 1997; Zhao et al. 1998) also caused nuclear translocation of GFP-Crzlp. Furthermore, other treatments that do not activate calcineurin/Crz1-dependent transcription (i.e., incubation with $200 \mathrm{mM} \mathrm{MgCl}_{2}$ or 800 $\mathrm{mm} \mathrm{KCl}$ ) failed to induce the nuclear translocation of Crzlp (data not shown).

The nuclear localization of Crzlp was transient, and in most cells cytosolic localization of GFP-Crzlp resumed 60-90 min after $\mathrm{Ca}^{2+}$ addition (Fig. 3, cf. B and C). A second addition of $\mathrm{Ca}^{2+}$ to cells at this time induced another cycle of GFP-Crzlp nuclear translocation, suggesting that the loss of GFP-Crzlp nuclear localization reflects the return of cytosolic $\left[\mathrm{Ca}^{2+}\right]$ to resting levels (data not shown). Yeast cells sequester $\mathrm{Ca}^{2+}$ into intracellular compartments by several mechanisms, and measurements of cytosolic $\left[\mathrm{Ca}^{2+}\right]$ show that $\mathrm{Ca}^{2+}$ levels decrease quickly after addition of $\mathrm{Ca}^{2+}$ to the medium

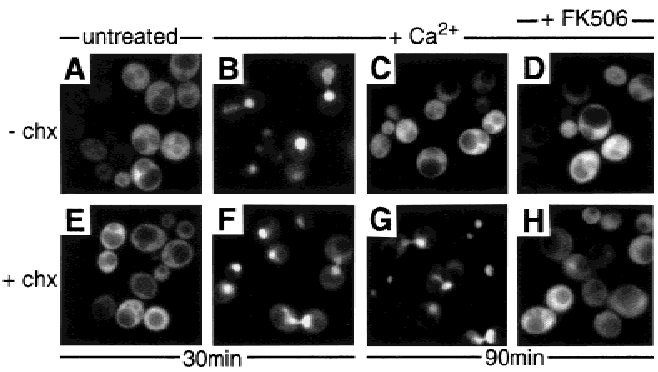

Figure 3. GFP-Crzl shuttles from the nucleus to the cytoplasm and nuclear localization requires calcineurin activity. Log-phase cultures of strain ASY472 containing GFP-CRZ1 were grown at $21^{\circ} \mathrm{C}$ and analyzed by fluorescence microscopy to determine GFP-Crzlp localization. $(E-H)$ Cells incubated for 2 hr with cycloheximide prior to other manipulations described $(+\mathrm{chx}) \cdot(A-D)$ Cells not incubated with cycloheximide (-chx). $(B, F)$ At $t=0 \mathrm{~min}, \mathrm{CaCl}_{2}$ was added to one aliquot of each culture $(200 \mathrm{~mm})$ and cells were observed at $t=30 \mathrm{~min} ;(A, E)$ Equivalent cells not exposed to $\mathrm{Ca}^{2+} .(D, H)$ At $t=60 \mathrm{~min}$ an aliquot of each $\mathrm{Ca}^{2+}$-treated culture was incubated with $3 \mu \mathrm{g} / \mathrm{ml}$ FK506 and observed at $t=90 \mathrm{~min} .(C, G)$ Cells incubated with $\mathrm{Ca}^{2+}$ for 90 min, not treated with FK506. 
(Miseta et al. 1999). Consistent with this idea, the return of GFP-Crzlp to the cytosol after $\mathrm{Ca}^{2+}$ addition was delayed in pmc1s mutants (data not shown). pmc1s cells lack a P-type ATPase that pumps $\mathrm{Ca}^{2+}$ into the yeast vacuole, and are defective in $\mathrm{Ca}^{2+}$ homeostasis (Cunningham and Fink 1994).

The reversible localization of GFP-Crzlp may be due to its shuttling in and out of the nucleus. Alternatively, Crzlp may be degraded after it translocates to the nucleus. In this case, protein synthesis would be required to reestablish Crzlp cytosolic localization after a $\left[\mathrm{Ca}^{2+}\right]$ rise. To distinguish between these two possibilites, we examined GFP-Crzlp localization in cells that had been treated with the protein synthesis inhibitor, cycloheximide. In cycloheximide-treated cells, addition of $\mathrm{Ca}^{2+}$ also resulted in rapid translocation of GFP-Crzlp to the nucleus (Fig. 3F). Ninety minutes after addition of $\mathrm{Ca}^{2+}$ to these cells, GFP-Crzlp remained nuclear (Fig. 3G). However, addition of FK506, a calcineurin inhibitor, caused relocalization of GFP-Crzlp to the cytosol (Fig. $3 \mathrm{H})$. These findings establish that GFP-Crzlp enters and exits the nucleus, and that the continuous activity of calcineurin is required to maintain GFP-Crzlp nuclear localization. Surprisingly, inhibiting protein synthesis prolonged the $\mathrm{Ca}^{2+}$-induced nuclear localization of GFPCrzlp (Fig. 3, cf. C and G). This may be due to impairment of $\mathrm{Ca}^{2+}$ sequestration. $\mathrm{Ca}^{2+}$ induces de novo protein synthesis of Pmclp (Cunningham and Fink 1996), thus cells treated with $\mathrm{Ca}^{2+}$ and cylcoheximide are defi-

A

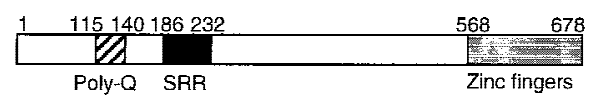

B

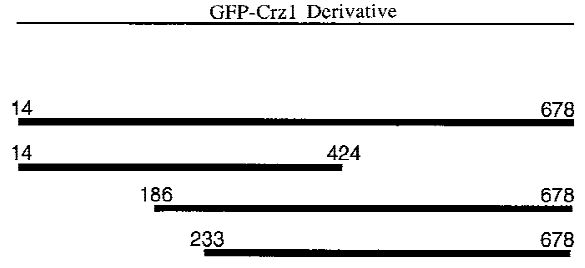

C

$$
\begin{array}{ll}
\text { Crz1 }_{186-208}: & \text { S SG IDS NY S DTES N YHT PYLY PQ } \\
\text { NFATC }_{179-201}: & \text { I }: \text { I I I I I I I I I I I I I I I EASSYESN Y SYPYASPQ }
\end{array}
$$

Figure 4. Localization of GFP-CRZ1 fusions. $(A)$ Diagram of functional domains identified within Crzlp. (Poly-Q) Polyglutamine tract; (SRR), serinerich region (see text and $C$ ); (zinc fingers) sequences that match the consensus for zinc finger DNA-binding motifs (Matheos et al. 1997; Stathopoulos and Cyert 1997). (B) Localization of GFP-Crzlp fusions in crz1s strains ASY834 (WT) and ASY835 (cnb1د) determined by fluorescence microscopy: (C), predominantly cytoplasmic localization; $(\mathrm{N})$ predominantly nuclear localization; (N/C) localization to both cytosol and nucleus. Localization was observed in resting cells (UT) and cells incubated at $21^{\circ} \mathrm{C}$ for 10 min with 200 mM CaCl $2\left(+\mathrm{Ca}^{2+}\right) \cdot(C)$ Crzlp SRR shares sequence similarity with the NFATc SRR. Alignment of NF-ATc (Northrop et al. 1994) and Crzlp (Matheos et al. 1997; Stathopoulos and Cyert 1997) amino acid sequences were analyzed by the ALION program (C.G. Nevill-Manning, C. N. Huang, and D. L. Brutlag, pers. comm.; http://motif.stanford.edu/alion//. cient for this $\mathrm{Ca}^{2+}$-ATPase. Similarly, cycloheximide may alter the abundance or activity of additional proteins involved in $\mathrm{Ca}^{2+}$ homeostasis.

Next, we further investigated Crzlp to determine which regions of this protein (Fig. 4A) are required for calcineurin-dependent regulation of its localization. We constructed a series of GFP fusions containing different amounts of Crzlp and examined the localization of these fusion proteins (Fig. 4B). A GFP-Crz1 fusion lacking either the carboxy-terminal 254 amino acids of Crzlp (GFP-Crz1 ${ }_{14-424}$ ) or the amino-terminal 185 residues of Crzlp (GFP-Crz1 ${ }_{186-678}$ ) showed $\mathrm{Ca}^{2+}$-induced, calcineurin-dependent nuclear localization that was indistinguishable from that of the full-length protein (Fig. 4B). These proteins also displayed a calcineurin-dependent change in apparent molecular mass (data not shown). Thus, these regions are dispensible for calcineurin-dependent regulation of Crzlp localization and phosphoryation. In contrast, a fusion lacking the amino-terminal (GFP-Crzl $1_{233-678}$ ) showed partial localization to the nucleus both in wild-type cells grown under standard conditions and in calcineurinmutant cells grown either under standard conditions nuclear localization was somewhat independent of calcineurin, although addition of $\mathrm{Ca}^{2+}$ to cells containing protein further increased nuclear localization by a calcineurin-dependent mechanism. Furthermore, the apparent molecular mass of GFP-Crz1 ${ }_{233-678}$ was identical in wild-type and calcineurin-mutant cells, suggesting that the deletion of amino acids 186232 disrupted the phosphorylation of Crzlp (data not shown). These results suggest that amino acids 186-232 of Crzlp are required for calcineurin-dependent regulation of its localization and phosphorylation. Examination of this region revealed that it shares sequence similarity to a domain of the NF-ATc transcription factor called the SRR, or serine rich region (Beals et al. 1997; Fig. 4C). Several serine residues in the NF-ATc SRR are thought to be dephosphorylated by calcineurin in vivo, resulting in exposure of a nuclear localization sequence (NLS) and import of NF-AT to the nucleus (Beals et al. 1997).

We studied the function of the SRR homology region of Crzlp (amino acids 186-232) further by constructing a GFP-Crzlp fusion that lacks only this region (GFP-Crz $\left.1^{\text {SRR }}\right)$. GFP-

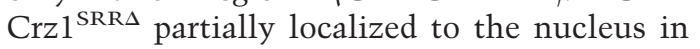
the absence of $\mathrm{Ca}^{2+}$ and calcineurin (Fig. 5A). In comparison, GFP-Crzlp is cytosolic under these conditions. Next, we investigated the ability of GFP-Crz $1^{\text {SRR } \Delta}$ to direct expression of a CDRE-lacZ reporter gene. Cells containing GFP-Crzlp produced high levels of $\beta$-galactosidase from CDRE-lac $Z$ in the presence of $\mathrm{Ca}^{2+}$ (Fig. 5B). This expression was inhibited by addition of the calcineurin inhibitor, FK520. In contrast, cells containing GFP-Crz1 ${ }^{\mathrm{SRR} \Delta}$ ex- 
A

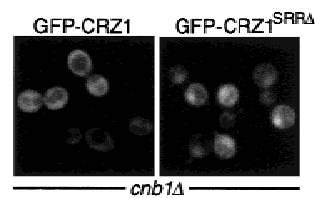

B

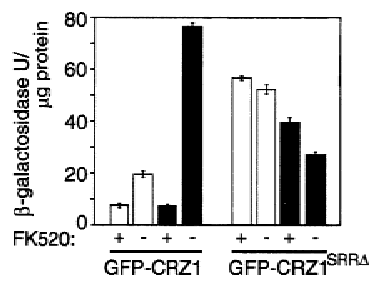

D

Strain:

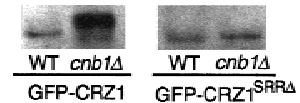

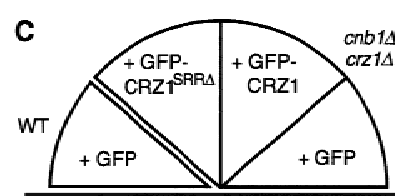

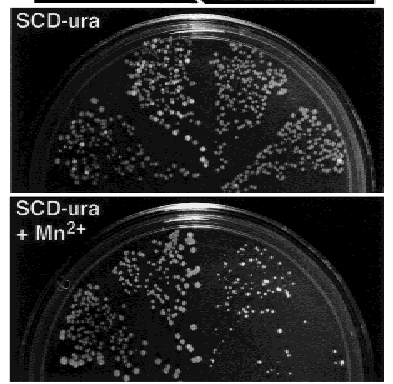

Figure 5. The SRR is required for calcineurin-dependent regulation of Crzlp localization, activity, and phosphorylation. $(A)$ GFP-CRZ1 ${ }^{\text {SRR } \Delta}$ displays partial nuclear localization in $c n b 1 \Delta$ cells. The localization of GFP fusions in crz1s cells ASY835 (cnb1s) containing either plasmids pAMS463 (GFP-Crzlp) or pAMS490 (GFP-CRZ1 ${ }^{\text {SRR } \Delta}$ is shown. (B) GFP-CRZ1 ${ }^{\text {SRR } \Delta}$ directs calcineurin-independent transcription. Cells of crz1s strains ASY834 (WT) or ASY835 (cnb1د) containing the CDRE-lacZ reporter (pBJ306) and either plasmids pAMS463 (GFP-Crz1p) or pAMS490 (GFP-CRZ1 ${ }^{S R R \Delta}$ ) were grown in synthetic medium at $21^{\circ} \mathrm{C}$ for $6 \mathrm{hr}$ with or without FK520 $(3 \mu \mathrm{g} / \mathrm{ml})$ and inducing treatments. $\beta$-Galactosidase activity is reported for extract of cells that were either untreated (open bars) or treated with 200 $\mathrm{mM} \mathrm{CaCl}_{2}$ (solid bars). $\beta$-Galactosidase activities were normalized to the amount of protein in extracts from one representative experiment. Each extract was assayed in triplicate and the S.D. is representative of the error between these samples. $(C)$ GFP-CRZ1 ${ }^{\text {SRR } \Delta}$ confers $\mathrm{Mn}^{2+}$ tolerance to calcineurin-deficient cells. Yeast strains were plated onto synthetic medium containing $4 \mathrm{mM} \mathrm{MnCl}_{2}$ and grown at $30^{\circ} \mathrm{C}$ for 3 days. (WT + GFP). Strain YPH499 containing pGFP-NFUS; (cnb1s crz1s + GFPCRZ1 ${ }^{\text {SRR } \Delta}$, strain ASY835 containing pAMS490; (cnb1 $c r z 1 \Delta$ + GFP-CRZ1). Strain ASY835 containing pAMS463. $(D)$ GFP-CRZ1 ${ }^{\text {SRR } \Delta}$ does not show a calcineurin-dependent difference in apparent molecular mass. Equal amounts of extracts

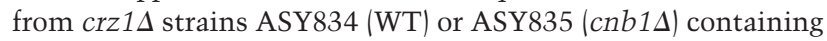
different GFP-Crzlp constructs [pAMS463 (GFP-CRZ1) or pAMS490 (GFP-CRZ1 $\left.{ }^{\text {SRR }}\right)$ ) were analyzed by Western blotting (see Methods).

pressed high levels of $\beta$-galactosidase from CDRE-lac $Z$ independent of $\mathrm{Ca}^{2+}$ addition, and expression was not decreased by addition of FK520 (Fig. 5B). Note that GFPCrzl $1^{\text {SRR } \Delta}$ is expressed at a lower level than GFP-Crzlp in vivo, so the absolute amount of transcription directed by these two proteins cannot be compared (data not shown).

We also examined the growth properties of strains expressing either GFP-Crzlp or GFP-Crzl ${ }^{\text {SRR } \Delta}$. Strains lacking calcineurin fail to grow on medium containing $\mathrm{Mn}^{2+}$ due, in part, to the absence of calcineurin/Crzlpdependent transcription (Matheos et al. 1997; Stathopou-

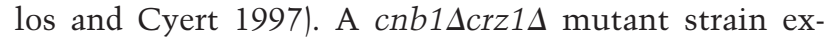
pressing GFP-Crz1 $1^{\text {SRR } \Delta}$ grew significantly better in the presence of $\mathrm{Mn}^{2+}$ than the same strain expressing GFP-

Crzlp (Fig. 5C). These observations are consistent with the expression of $\beta$-galactosidase from CDRE-lac $Z$ and indicate that GFP-Crz1 ${ }^{\text {SRR } \Delta}$ confers calcineurin-independent gene expression in vivo.

Finally, the apparent molecular mass of GFP-Crz1 ${ }^{\text {SRR } \Delta}$ does not differ significantly in wild-type versus calcineurin-mutant cells, suggesting that its phosphorylation state is not modulated by calcineurin (Fig. 5D). Together, all of the findings concerning GFP-Crzl ${ }^{\mathrm{SRR} \Delta}$ indicate that the SRR region of Crzlp (amino acids 186-232) plays a critical role in mediating the calcineurin-dependent regulation of Crzlp phosphorylation, localization, and activity.

These studies add significantly to our understanding of $\mathrm{Ca}^{2+}$-dependent signal transduction in yeast by establishing that calcineurin controls gene expression through modulation of Crzlp localization. Furthermore, we demonstrate that the phosphorylation state of Crzlp is regulated by calcineurin in vivo and that calcineurin dephosphorylates Crzlp in vitro. Thus, Crzlp is the first protein identified as a substrate of calcineurin in yeast.

Our observations support the following model for the regulation of Crzlp by calcineurin: In its phosphorylated state, Crzlp resides primarily in the cytosol, and the expression of Crzl-dependent genes is low. Once calcineurin is activated (i.e., in response to addition of $\mathrm{Ca}^{2+}$, high temperature, $\mathrm{Na}^{+}$, etc.) it dephosphorylates Crzlp, which allows its nuclear translocation, and promotes Crzlp-dependent transcription. We cannot yet determine whether, in addition to its localization, other aspects of Crzlp function are also regulated by calcineurindependent dephosphorylation. Much like the SRR domain of NF-ATc, the SRR domain of Crzlp serves an inhibitory role, such that when this domain is present, Crzl remains cytosolic under low $\mathrm{Ca}^{2+}$ conditions or in the absence of calcineurin. The presence of the SRR domain is required not only for calcineurin-dependent regulation of Crzlp localization and activity, but also for calcineurin-dependent regulation of Crzlp phosphorylation. Thus, the SRR domain may contain the major phosphorylation sites of Crzlp that are dephosphorylated by calcineurin or may be required for recognition of Crzlp by one or more protein kinases. Phosphorylation can modify the localization of a protein by regulating its rate of its nuclear import or export or both (Jans and Hubner 1996; Beals et al. 1997; Kaffman et al. 1998a, 1998b). Our future studies of Crzlp will address the mechanism by which the phosphorylation state of Crzlp affects the kinetics of its transport into and/or out of the nucleus.

$\mathrm{Ca}^{2+}$ acts as a signaling molecule in virtually all eukaryotic cells. Although the external conditions that evoke $\mathrm{Ca}^{2+}$ signals vary widely among cell types, many of the intracellular events that occur downstream of a $\mathrm{Ca}^{2+}$ rise are highly conserved. Calcineurin, the $\mathrm{Ca}^{2+} /$ calmodulin-regulated phosphatase, effects the nuclear translocation and activation of the Crzlp and NF-AT transcription factors in yeast and mammalian cells, respectively. The mechanisms of these signaling responses are strikingly similar, although the Crzlp and NF-AT transcription factors share only limited sequence simi- 
larity. These findings demonstrate that the rapid and reversible control of gene expression via regulation of nuclear localization is a fundamental and highly conserved component of $\mathrm{Ca}^{2+}$-induced calcineurin-mediated signaling pathways.

\section{Materials and methods}

\section{Strains and plasmids}

All yeast strains have been described previously (Cyert and Thorner 1992; Stathopoulos and Cyert 1997). Yeast medium and culture conditions have also been described previously (Stathopoulos and Cyert 1997). Growth conditions used for GFP localization studies are described below. A stock solution of FK506 or FK520 (Fugisawa, Deerfield, IL, and Merck Co., Rahway, NJ, repectively; $20 \mathrm{mg} / \mathrm{ml}$ in $90 \%$ ethanol, $10 \%$ Tween 20 ) was also added to liquid medium where noted. The CDRE-lacZ reporter gene within pBJ306 (B. Jiang and M.S. Cyert, in prep.) contains four copies of the CDRE driving lacZ from a CYC1 minimal promoter and was integrated at the URA3 locus after linearization with StuI and selection for tryptophan prototrophy. The construction of plasmids expressing HACRZ1 on a high-copy number plasmid has been described previously (Stathopoulos and Cyert 1997). A series of CRZ1 fusions to the carboxyl terminus of GFP (pAMS463, pAMS435, pAMS469, pAMS473, pAMS490) were constructed by cloning and PCR with the GFP fusion vector, pGFPNFUS (Niedenthal et al. 1996) and portions of the CRZ1 gene from pAM435. Detailed descriptions of plasmids used in this study are available on request.

Cell extract preparation, immunoprecipitation, and Western blotting For the analysis of Crzlp electrophoretic mobility, whole-cell extracts $(\sim 5 \mu \mathrm{g} / \mu \mathrm{l})$ were prepared from cultures of strains ASY635 and ASY635 containing HA-tagged Crzlp (pAMS446) grown at $21^{\circ} \mathrm{C}$ to $\log$ phase essentially as described (Stathopoulos and Cyert 1997) with the following exception: Cells were resuspendend in RIPA buffer [20 mм Tris- $\mathrm{HCl}(\mathrm{pH}$ 7.6), 2 mm EDTA, $150 \mathrm{~mm} \mathrm{NaCl}, 1 \%$ Triton X-100, $1 \%$ Na-deoxycholate, $0.1 \%$ SDS, $1.0 \mathrm{~mm}$ DTT] with protease inhibitors (1 mm benzamidine$\mathrm{HCl}, 1 \mathrm{~mm}$ PMSF, and $5 \mu \mathrm{g} / \mathrm{ml}$ each pepstatin, aprotinin, and leupeptin), and phosphatase inhibitors $(5 \mathrm{~mm}$ sodium fluoride, $5 \mathrm{~mm}$ sodium phosphate, $10 \mathrm{~mm}$ sodium pyrophosphate, $10 \mathrm{~mm}$ sodium molybdate, $5 \mathrm{~mm}$ EDTA, and 5 mм EGTA) before lysis. For Western blots, $5 \mu$ of extract was separated on a $7.5 \%$ polyacrylamide-SDS gel, transferred to nitrocellulose, incubated with anti-GFP antibody (Kahana et al. 1995), HRPconjugated secondary antibody, and visualized with ECL (reagents from Amersham). For immunoprecipitation, $30 \mu \mathrm{l}$ of cell extract was mixed with $30 \mu \mathrm{l}$ of rabbit polyclonal antibody HA.11 (BabCo) and rotated overnight at $4^{\circ} \mathrm{C}$. A total of $10 \mu \mathrm{l}$ of protein-A agarose beads (SIGMA) were added, and after $4 \mathrm{hr}$ at $4^{\circ} \mathrm{C}$ the beads were washed three times with RIPA buffer, and resuspended in CP buffer [50 mM Tris-HCl, $(\mathrm{pH} 7.5), 10 \mathrm{~mm}$ $\mathrm{MgCl}_{2}, 5 \mathrm{~mm}$ DTT). When noted, some of the following additions were also included with CP buffer: $\mathrm{CaCl}_{2}(20 \mathrm{mM}$ ), calmodulin (Sigma, 83 units), calcineurin (Sigma, 0.8 units), EGTA (100 mm), and cypermethrin (Calbiochem, $100 \mu \mathrm{M}$ ). Immunoprecipitates were then incubated at $30^{\circ} \mathrm{C}$ for $30 \mathrm{~min}$, separated on an $8 \%$ polyacrylamide gel, and immunoblotted with anti-HA antibodies (Boehringer-Mannheim).

\section{Examination of GFP-CRZ1}

Live yeast cells containing GFP-Crzlp fusions were prepared for visualization as follows: Log-phase cultures $\left(\mathrm{OD}_{600}\right.$ of $\left.1.0-1.5\right)$ were grown at $21^{\circ} \mathrm{C}$ in synthetic medium with $60 \mu \mathrm{g} / \mathrm{ml}$ additional adenine to reduce the background fluorescence of ade2 mutants, ammonium chloride substituted for ammonium sulfate to reduce precipitation on $\mathrm{Ca}^{2+}$ addition, and in the absence of methionine to induce high-level expression from the MET25 promoter of pGFP-NFUS vector. Cells were harvested and concentrated 10- to 20-fold before visualization. When noted, cells were incubated briefly with $1 \mathrm{ng} / \mathrm{ml}$ DAPI (Sigma) prior to visualization to stain DNA, or for $2 \mathrm{hr}$ with $10 \mu \mathrm{g} / \mathrm{ml}$ cycloyheximide (Sigma) to inhibit protein synthesis. Cells were viewed at room temperature on a Axioskop microscope (Carl Zeiss, Thornwood, NY) equipped with Nomarski differential interference contrast and fluorescence optics with a $100 \times / 1.3$ objective lens and HBO100 mercury lamp. GFP and nuclear staining were visualized with fluorescein and DAPI filter sets, respectively (Chroma Technology, Brattleboro, VT).

\section{Acknowledgments}

We thank Jerry Crabtree, Jeremy Thorner, and members of the Cyert laboratory for comments on the manuscript, Fujisawa for supplying FK506, Merck for supplying FK520, and Pam Silver for supplying antiGFP antibody. We thank Kim Williams for identifying the sequence similarity between Crzlp and NF-AT. We thank Renée Polizotto and John Gerontides for helpful discussion and Tim Stearns for his generous advice concerning fluorescence microscopy. This work was supported from the following sources: National Institutes of Health research grant GM-48728, The National Science Foundation Young Investigator Award MCB-9357017, biomedical scholar award 92-42 from the Lucille P. Markey Charitable Trust, and funds from Proctor and Gamble (all to M.S.C.).

The publication costs of this article were defrayed in part by payment of page charges. This article must therefore be hereby marked 'advertisement' in accordance with 18 USC section 1734 solely to indicate this fact.

\section{References}

Beals, C.R., N.A. Clipstone, S.N. Ho, and G.R. Crabtree. 1997. Nuclear localization of NF-ATc by a calcineurin-dependent, cyclosporin-sensitive intramolecular interaction. Genes \& Dev. 11: 824-834.

Clipstone, N.A. and G.R. Crabtree. 1992. Identification of calcineurin as a key signalling enzyme in T-lymphocyte activation. Nature 357: 695-697.

Cunningham, K.W. and G.R. Fink. 1994. Calcineurin-dependent growth control in Saccharomyces cerevisiae mutants lacking PMC1, a homolog of plasma membrane $\mathrm{Ca}^{2+}$ ATPases. J. Cell Biol. 124: 351-363.

- 1996. Calcineurin inhibits VCX1-dependent $\mathrm{H}^{+} / \mathrm{Ca}^{2+}$ exchange and induces $\mathrm{Ca}^{2+}$-ATPases in Saccharomyces cerevisiae. Mol. Cell. Biol. 16: 2226-2237.

Cyert, M.S. and J. Thorner. 1992. Regulatory subunit (CNB1 gene product) of yeast $\mathrm{Ca}^{2+} /$ calmodulin-dependent phosphoprotein phosphatases is required for adaptation to pheromone. Mol. Cell. Biol. 12: 34603469.

Cyert, M.S., R. Kunisawa, D. Kaim, and J. Thorner. 1991. Yeast has homologs (CNA1 and CNA2 gene products) of mammalian calcineurin, a calmodulin-regulated phosphoprotein phosphatase. Proc. Nat. Acad. Sci. 88: 7376-7380.

de la Pompa, J., L. Timmerman, H. Takimoto, H. Yoshida, A. Elia, E. Samper, J. Potter, A. Wakeham, L. Marengere, B. Langille, G. Crabtree, and T. Mak. 1998. Role of the NF-ATc transcription factor in morphogenesis of cardiac valves and septum. Nature 392: 182-186.

Flanagan, W., B. Corthesy, R. Bram, and G. Crabtree. 1991. Nuclear association of a T-cell transcription factor blocked by FK-506 and cyclosporin A. Nature 352: 803-807.

Friedman, J. and I. Weissman. 1991. Two cytoplasmic candidates for immunophilin action are revealed by affinity for a new cyclophilin: One in the presence and one in the absence of CsA. Cell 66: 799-806.

Jain, J., P.G. McCaffrey, Z. Miner, T.K. Kerppola, J.N. Lambert, G.L. Verdine, T. Curran, and A. Rao. 1993. The T-cell transcription factor NFATp is a substrate for calcineurin and interacts with Fos and Jun. Nature 365: 352-355.

Jans, D.A. and S. Hubner. 1996. Regulation of protein transport to the nucleus: Central role of phosphorylation. Physiol. Rev. 76: 651-685.

Kaffman, A., N.M. Rank, E.M. O'Neill, L.S. Huang, and E.K. O'Shea. 1998a. The receptor MSN5 exports the phosphorylated transcription factor Pho4 out of the nucleus. Nature 396: 482-486.

Kaffman, A., N.M. Rank, and E.K. O'Shea. 1998b. Phosphorylation regulates association of the transcription factor Pho4 with its import receptor Pse1/Kap121. Genes \& Dev. 12: 2673-2683.

Kahana, J., B. Schnapp, and P. Silver. 1995. Kinetics of spindle pole body separation in budding yeast. Proc. Nat1. Acad. Sci. 92: 9707-9711.

Liu, J., J.J.D. Farmer, W.L. Lane, J. Friedman, I. Weissman, and S.L. Schreiber. 1991a. Calcineurin is a common target of cyclophilin-CsA and FKBP-FK506 complexes. Cell 66: 807-815.

Liu, Y., S. Ishii, M. Tokai, H. Tsutsumi, O. Ohke, R. Akada, K. Tanaka, E. Tsuchiya, S. Fukui, and T. Miyakawa. 1991b. The Saccharomyces cerevisiae genes (CMP1 and CMP2) encoding calmodulin-binding proteins homologous to the catalytic subunit of mammalian protein phosphatase 2B. Mol. \& Gen. Genet. 227: 52-59. 
Matheos, D., T. Kingsbury, U. Ahsan, and K. Cunningham. 1997. Tcnlp/ Crzlp, a calcineurin-dependent transcription factor that differentially regulates gene expression in Saccharomyces cerevisiae. Genes \& Dev. 11: 3445-3458.

Mazur, P., N. Morin, W. Baginsky, M. El-Sherbeini, J.A. Clemas, J.B. Nielsen, and F. Foor. 1995. Differential expression and function of two homologous subunits of yeast 1,3- $\beta$-D-glucan synthase. Mol. Cell. Biol. 15: 5671-5681.

Mendoza, I., F. Rubio, A. Rodriguez-Navarro, and J.M. Pardo. 1994. The protein phosphatase calcineurin is essential for $\mathrm{NaCl}$ tolerance of Saccharomyces cerevisiae. J. Biol. Chem. 269: 8792-8796.

Miseta, A., L. Fu, R. Kellermayer, J. Buckley, and D. Bedwell. 1999. The Golgi apparatus plays a significant role in the maintenance of $\mathrm{Ca}^{2+}$ homeostasis in the vps334 vacuolar biogenesis mutant of Saccharomyces cerevisiae. J. Biol. Chem. 274: 5939-5947.

Molkentin, J., J. Lu, C. Antos, B. Markham, J. Richardson, J. Robbins, S. Grant, and E. Olson. 1998. A calcineurin-dependent transcriptional pathway for cardiac hypertrophy. Cell 93: 215-228.

Moser, M.J., J.R. Geiser, and T.N. Davis. 1996. $\mathrm{Ca}^{2+}$-calmodulin promotes survival of pheromone-induced growth arrest by activation of calcineurin and $\mathrm{Ca}^{2+}$-calmodulin-dependent protein kinase. Mol Cell. Biol. 16: 4824-4831.

Nakamura, T., Y. Liu, D. Hirata, H. Namba, S. Harada, T. Hirokawa, and T. Miyakawa. 1993. Protein phosphatase type 2B (calcineurin)-mediated, FK506-sensitive regulation of intracellular ions in yeast is an important determinant for adaptation to high salt stress conditions. EMBO J. 12: 4063-4071.

Niedenthal, R.K., L. Riles, M. Johnston, and J.H. Hegemann. 1996. Green fluorescent protein as a marker for gene expression and subcellular localization in budding yeast. Yeast 12: 773-786.

Northrop, J.P., S.N. Ho, L. Chen, D.J. Thomas, L.A. Timmerman, G.P. Nolan, A. Admon, and G.R. Crabtree. 1994. NF-AT components define a family of transcription factors targeted in T-cell activation Nature 369: 497-502.

O'Keefe, S.J., J. Tamura, R.L. Kincaid, M.J. Tocci, and E.A. O'Neill. 1992. FK506- and CsA-sensitive activation of the interleukin-2 promoter by calcineurin. Nature 357: 692-694.

Pozos, T.C., I. Sekler, and M.S. Cyert. 1996. The product of HUM1, novel yeast gene, is required for vacuolar $\mathrm{Ca}^{2+} / \mathrm{H}^{+}$exchange and is related to mammalian $\mathrm{Na}^{+} / \mathrm{Ca}^{2+}$ exchangers. Mol. Cell. Biol. 16: $3730-3741$.

Ranger, A., M. Grusby, M. Hodge, E. Gravallese, F. de la Brousse, T. Hoey, C. Mickanin, H. Baldwin, and L. Glimcher. 1998. The transcription factor NF-ATc is essential for cardiac valve formation. $\mathrm{Na}$ ture 392: 186-190.

Rao, A., C. Luo, and P.G. Hogan. 1997. Transcription factors of the NFAT family: Regulation and function. Ann. Rev. Immunol. 15: 707-747.

Shaw, K., A. Ho, A. Raghavan, J. Kim, J. Jian, J. Park, S. Sharma, A. Rao, and P. Hogan. 1995. Immunosuppressive drugs prevent a rapid dephosphorylation of transcription factor NFATl in stimulated immune cells. Proc. Natl. Acad. Sci. 92: 11205-11209.

Stathopoulos, A.M. and M.S. Cyert. 1997. Calcineurin acts through the CRZ1/TCN1-encoded transcription factor to regulate gene expression in yeast. Genes \& Dev. 11: 3432-3444.

Withee, J.L., J. Mulholland, R. Jeng, and M.S. Cyert. 1997. An essential role of the pheromone-dependent $\mathrm{Ca}^{2+}$ signal is to activate yeast calcineurin. Mol. Biol. Cell 8: 263-277.

Zhao, C., U.S. Jung, P. Garrett-Engele, T. Roe, M.S. Cyert, and D.E. Levin. 1998. Temperature-induced expression of yeast FKS2 is under the dual control of protein kinase $\mathrm{C}$ and calcineurin. Mol. Cell. Biol. 18: 1013-1022. 


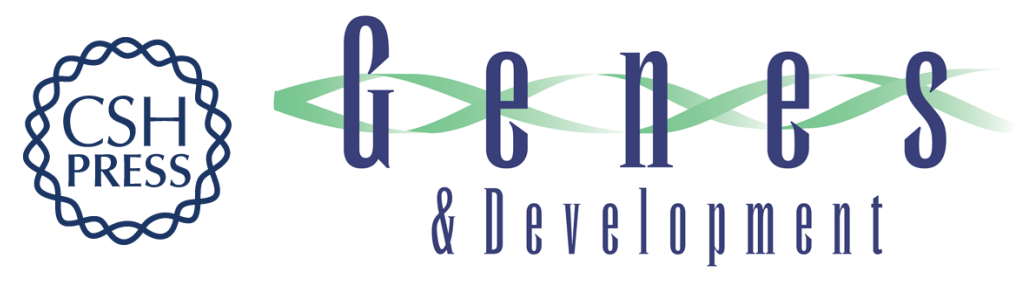

\section{Yeast calcineurin regulates nuclear localization of the Crz1p transcription factor through dephosphorylation}

Angelike Stathopoulos-Gerontides, Jim Jun Guo and Martha S. Cyert

Genes Dev. 1999, 13:

References This article cites 33 articles, 17 of which can be accessed free at:

http://genesdev.cshlp.org/content/13/7/798.full.html\#ref-list-1

License

Email Alerting Receive free email alerts when new articles cite this article - sign up in the box at the top Service right corner of the article or click here.

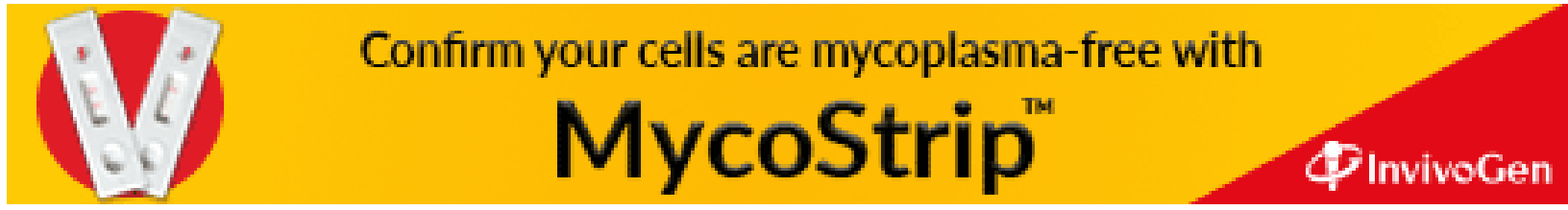

